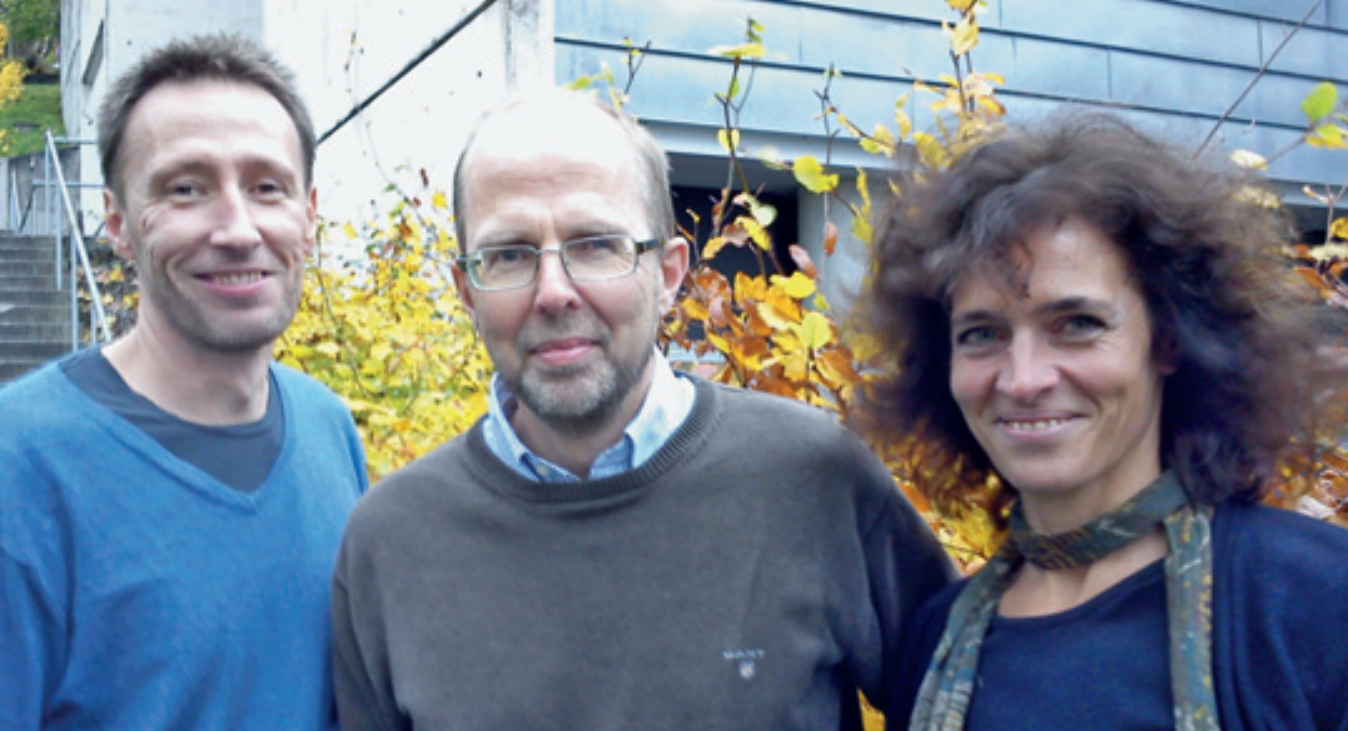

Stefan Johansson, Jan Haavik og Anne Halmøy. Foto Ingeborg Winge

\title{
Arvelig mangel på serotonin gir økt risiko for AD/HD
}

\author{
Barna til kvinner med en genetisk betinget defekt i produksjonen \\ av serotonin har økt risko for AD/HD og andre psykiske lidelser.
}

Det viser en norsk studie.

Serotonin er både et hormon og en nevrotransmitter som medierer ulike fysiologiske funksjoner hos mennesker. Virveldyr har gener for to ulike enzymer som er ansvarlig for serotoninproduksjonen i henholdsvis perifere vev (tryptofanhydroksylase 1, TPH1) og hjernen (tryptofanhydroksylase 2, TPH2). Dyrestudier har vist at maternelt produsert serotonin, dannet ved hjelp av TPH1, også har en effekt på den tidlige embryonale hjerneutviklingen.

Ved å sekvensere disse genene i 646 norske AD/HD-pasienter og kontrollpersoner fant man 38 individer med mutasjoner i TPH1-genet. Funksjonelle studier viste at de fleste av disse mutasjonene ga nedsatt TPH1-enzymfunksjon og sannsynligvis også redusert serotoninproduksjon. Barna til kvinner med TPH1-mutasjoner hadde mer symptomer på AD/HD enn kontrollpersonenes barn eller barna til menn med samme mutasjon.

- Tidligere forskning tyder på at visse genetiske variasjoner i TPH1 kan være forbundet med økt risiko for psykiske lidelser, sier førsteforfatter Anne Halmøy. Hun er psykiater og stipendiat ved Institutt for biomedisin, Universitetet i Bergen. - Ut fra denne studien kan mye tyde på at effekten av disse genetiske variantene kan være mediert under den tidlige fosterutviklingen, $o g$ at serotoninmangel under graviditeten er en risikofaktor for flere ulike tilstander (1). Siden dette er den første studien der en slik sammenheng er påvist, må funnene replikeres i flere pasientmaterialer, sier Halmøy.

\section{AD/HD-forskning i Bergen}

Studien utgår fra et tematisk omfattende og langsiktig (2004-25) forskningsprosjekt ved
Universitetet i Bergen. AD/HD-pasienter og kontrollpersoner blir rekruttert fra hele landet. Prosjektet ledes av Jan Haavik, professor i biomedisin ved Universitetet i Bergen og psykiater ved Haukeland universitetssykehus. Pasienter eller klinikere som ønsker å delta, kan henvende seg til prosjektsekretariatet (http://adhdprosjektet.b.uib.no/).

Prosjektgruppen er tverrfaglig sammensatt og representerer fire institutter og to fakulteter i tillegg til Senter for medisinsk genetikk og molekylærmedisin og Psykiatrisk divisjon ved Haukeland universitetssykehus. Metodene strekker seg fra klinisk psykiatrisk forskning via epidemiologi, nevropsykologi, funksjonell, strukturell og spektroskopisk hjerneavbildning (MRI) til genetisk og molekylær karakterisering av kandidatgener. Det langsiktige målet er ny innsikt $\mathrm{i}$ kliniske uttrykk for og årsaker til $\mathrm{AD} / \mathrm{HD}$, noe som kan lede til forbedret diagnostikk samt muligheter for forebygging og behandling.

Stiftelsen Kristian Gerhard Jebsen bevilget nylig 16 millioner kroner til å etablere K.G. Jebsen Senter for forskning på nevropsykiatriske lidelser ved Universitetet i Bergen. Professor Jan Haavik vil lede det nye senteret, der man vil studere årsaksfaktorer og mekanismer for vanlige psykiske lidelser, med hovedvekt på AD/HD og relaterte tilstander med svekket impulskontroll.

\section{Erlend Hem}

erlend.hem@medisin.uio.no

Tidsskriftet

\section{Litteratur}

Halmøy A, Johansson S, Winge I et al. Attentiondeficit/hyperactivity disorder symptoms in offspring of mothers with impaired serotonin produc tion. Arch Gen Psychiatry 2010; 67: 1033-43.

\section{Ordforklaringer}

AD/HD lattention deficit/hyperactivity disorder): Atferdssyndrom karakterisert ved konsentrasjonsvansker, hyperaktivitet og impulsivitet ltilsvarer hyperkinetisk forstyrrelse i ICD-10-systemet). Symptomene skal ha vært til stede fra barnealder og i en slik grad at de fører til problemer på flere områder, f.eks. på skole/jobb, sosialt, i forhold til familie. AD/HD er en av de vanligste psykiske lidelsene hos barn og ungdom. Tidligere trodde man at barn «vokste av seg» lidelsen, men fra 1970årene har det vært klart at de fleste med $A D / H D$ har vedvarende symptomer i voksenlivet. Prevalensstudier tyder også på at de fleste med $A D / H D$ er voksne. Både arvelige faktorer og miljøpåvirkninger synes å være involvert i patogenesen, men de konkrete årsaker til AD/HD er fortsatt ukjente.

Mutasjon: Permanent endring av den genetiske koden. Vanlige typer av mutasjoner er punktmutasjoner, som endrer en spesifikk base i DNA, insersjoner og delesjoner, der en eller flere baser blir tilført eller tatt vekk fra den normale sekvensen, og translokasjoner, der hele kromosomdeler blir utvekslet mellom kromosomene. I denne studien har forskerne spesielt studert mutasjoner som fører til forandring av aminosyresekvens (missense-mutasjoner) eller avbrutt translasjon (non-sense-mutasjoner) av proteiner. Mutasjoner kan oppdages ved hjelp av DNAsekvensering, som inntil nylig var en langsom og ressurskrevende metode. Innføring av ny teknologi (massiv parallell sekvensering, også kalt «nestegenerasjonssekvensering») gjør det mulig å øke tilgangen på genetisk informasjon dramatisk.

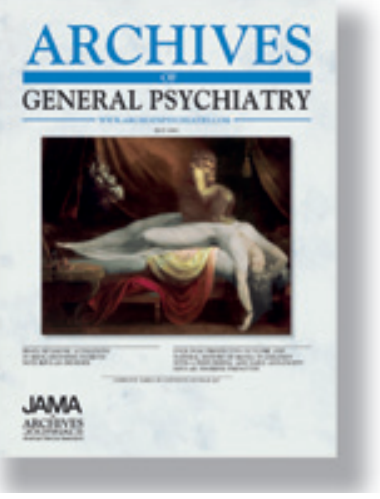

Artikkelen står i oktoberutgaven 2010 av Archives of General Psychiatry (http:// archpsyc.ama-assn.org), som er et av de høyest rangerte psykiatriske tidsskrifter. Photograph copyright Detroit Institute of Arts, Detroit, Michigan, USA

\section{Tips oss}

Er du i ferd med å publisere eller har du nylig publisert eller har du nylig publisert tidsskrift? Send tips til erlend.hem@medisin.uio.no 